\title{
Characteristics of pediatric traumatic brain injury: study from Wongsonegoro Regional Public Hospital in Semarang
}

\author{
DOI: https://doi.org/10.22435/hsji.v12i1.4076
}

\author{
Andrew Robert Diyo ${ }^{1}$, Nadisa Tiofunda Budiman², Natashia Olivia Christian², Riky Pratama² \\ ${ }^{1}$ Department of Surgery, Wongsonegoro General Hospital Semarang/Faculty of Medicine Tarumanagara \\ University Jakarta, Indonesia \\ ${ }^{2}$ Faculty of Medicine Tarumanagara University Jakarta, Indonesia
}

Corresponding author: Andrew Robert Diyo

Email: andrewdiyo@gmail.com

Received: November 19, 2020; Revised: April 6, 2021; Accepted: May 18, 2021.

\begin{abstract}
Background: Traumatic brain injury is one of the leading causes of morbidity and mortality in the world, as well as disability in the pediatric group. This study aimed to describe the characteristics of pediatric traumatic brain injury patients, considering the lack of data in Indonesia.

Methods: We conducted a descriptive-retrospective study at Wongsonegoro Regional Public Hospital Semarang. Data were extracted from medical records of patients admitted during the period of January 2017-December 2019 using a purposive sampling method.

Results: Out of 296 patients, most of the patients were male (59.13\%; 66.30\%). Based on age group, the highest percentage was found in the adolescent (11-18-year-old) (40.87\%) in operative patients and 5-10-yearold $(37.57 \%)$ in non-operative patients. The most common cause of traumatic brain injury in operative patients was falling from motor vehicle (37.39\%) while in non-operative patients was falling while playing (32.60\%). The most common type of injury in operative patients was epidural hematoma $(49.57 \%)$ and in non-operative patients was brain concussion (53.59\%). Most of the patients had minor head injury $(75.65 \% ; 81.22 \%)$. Most of operative patients spent 3-5 days (64.35\%) in the hospital while most of non-operative patients spent 1-3 days (72.37\%). Of all the subjects, the majority of patients recovered and discharged.
\end{abstract}

Conclusion: Falling from motor vehicle remains as the most common type of pediatric traumatic brain injury in this study. This study provides an overview of traumatic brain injury in children and shows the importance of enforcing driving rules and supervision by parents which play an important role in child safety. (Health Science Journal of Indonesia 2021;12(1):1-5)

Keywords: pediatric, traumatic brain injury, Indonesia

\begin{abstract}
Abstrak
Latar belakang: Cedera kepala merupakan salah satu penyebab utama morbiditas dan mortalitas di dunia, serta disabilitas pada kelompok pediatri. Penelitian ini bertujuan untuk mendeskripsikan karakteristik pasien pediatri dengan cedera kepala, mengingat minimnya data cedera kepala pada anak di Indonesia.
\end{abstract}

Metode: Penelitian ini merupakan penelitian deskriptif-retrospektif di RSUD Wongsonegoro Semarang. Data diambil dari rekam medis pasien anak yang dirawat selama periode Januari 2017-Desember 2019 dengan menggunakan metode purposive sampling.

Hasil: Dari 296 pasien, sebagian besar merupakan laki-laki (59,13\%; 66,30\%). Berdasarkan kelompok umur, persentase tertinggi pada kelompok operatif terdapat pada kelompok remaja (11-18 tahun) (40,87\%) dan pada kelompok non operatif terdapat pada kelompok usia 5-10 tahun (37,57\%). Penyebab tersering cedera kepala pada pasien operatif yakni jatuh dari kendaraan bermotor $(37,39 \%)$ sementara pada pasien non operatif penyebab tersering berupa jatuh saat bermain $(32,60 \%)$. Jenis cedera kepala tersering pada pasien operatif adalah Epidural Hematoma (49,57\%) dan pada pasien non-operatif berupa commotio cerebri $(53,59 \%)$. Kebanyakan pasien mengalami cedera kepala ringan $(75,65 \%$; 81,22\%). Sebagian besar pasien operatif dirawat selama 3-5 hari $(64,35 \%)$ sedangkan mayoritas pasien non operatif dirawat selama 1-3 hari $(72.37 \%)$ Dari semua subjek, mayoritas pasien sembuh dan dipulangkan.

Kesimpulan: Jatuh dari kendaraan bermotor merupakan jenis cedera kepala yang paling umum ditemukan dalam penelitian ini. Studi ini memberikan gambaran umum tentang cedera kepala pada anak dan menunjukkan pentingnya penegakan aturan dalam berkendara serta pengawasan oleh orang tua yang berperan penting dalam keselamatan anak. (Health Science Journal of Indonesia 2021;12(1):1-5)

Kata kunci: anak, cedera kepala, Indonesia 
Traumatic brain injury is one of the leading causes of high morbidity and mortality in the world. It is estimated that about 1.4 million people in the United States have experienced traumatic brain injury, of which 235,000 require treatment in a health facility, and 50,000 of whom have died. ${ }^{1}$ Even in children and adolescents, traumatic brain injury is one of the main causes of disability and death worldwide. One report in Europe in 2006 stated that the average number of fatal and non-fatal head injury cases in children was between 0.5 and 5.2 per 1,000 children. ${ }^{2}$ In Indonesia, it is reported that the average number of traumatic brain injury cases in Dr. Sutomo General Hospital from 2009 to 2013 was 1178 cases per year, with $6,1-11,2 \%$ mortality rates, while in Hasan Sadikin Hospital, the incidence of traumatic brain injury from 2008-2010 was 3578 cases. ${ }^{3,4} \mathrm{~A}$ study by Putra, reported 186 cases of traumatic brain injury at the Umbu Rara Meha Waingapu Regional General Hospital for the period of January 1, 2017 to December 31, 2018. ${ }^{5}$

In pediatric populations worldwide, the most common cause of traumatic brain injury in children aged 14 years is falling and in children aged over 14 years is traffic accidents, whether riding a motor vehicle or not. ${ }^{6}$ Dewi et al. ${ }^{7}$ reported 503 cases of pediatric traumatic brain injury at Cipto Mangunkusumo Hospital for the period of January 2004 until July 2005 with patients aged less than 15 years old. Most cases of pediatric traumatic brain injury are minor head injury that do not require hospitalization and can be immediately discharged after receiving initial treatment in the emergency unit, however, the prevalence of moderate to severe head injuries is not low either and has a risk of causing worse prognosis than patients with minor head injuries. ${ }^{6}$ Such disorders will certainly have a profound effect, not only on the child's life, but also on the life of the family, especially the parents.

This study examines the characteristics of traumatic brain injury in pediatrics. Considering that there are still few reports and data on head injuries, especially in Indonesia, this study is expected to help describing the characteristics of traumatic brain injury.

\section{METHODS}

This study is a retrospective descriptive study using medical records in Wongsonegoro Regional Public Hospital Semarang. The study population included all pediatric patients ( $\leq 18$ years) with traumatic brain injury at Wongsonegoro Regional Public Hospital Semarang. Wongsonegoro Regional Public Hospital Semarang was chosen for this study because the neurosurgical service at Wongsonegoro Regional Public Hospital Semarang covers several surrounding areas including Demak, Jepara, Grobogan, Pati, Blora and Rembang, thus having many referrals from those areas especially pediatric traumatic brain injury cases.

The study sample was taken using a purposive sampling method by including all pediatric patients ( $\leq 18$ years old) with traumatic brain injury, who underwent surgery and who did not during the period of January 1, 2017 to December 31, 2019. The inclusion criteria for this study were traumatic brain injury patients aged $\leq 18$ years old and were hospitalized. The exclusion criteria were incomplete medical records.

The statistical analysis of this study was in the form of a descriptive analysis which included gender, age, cause and type of injury based on ICD-10, Glasgow Coma Scale score, length of stay, and discharge condition in operative and non-operative patients. Data processing was carried out with SPSS version 25 and displayed frequency, percentage, and mean values.

This study was approved by The Ethics Committee of Wongsonegoro Regional Public Hospital with a letter number B/11055/070/X/2020.

\section{RESULTS}

This study was conducted by collecting medical records of pediatric patients with traumatic brain injury. Based on the data collected, the number of pediatric patients with traumatic brain injury was 296 patients. Of the 296 patients, there were 115 operative patients and 181 non-operative patients. In the operative group, it was found that the majority were male $(n=68 ; 59.13 \%)$ with most of them aged $11-18$ years old $(n=47 ; 40.87 \%)$. The most common cause of injury was falling from motor vehicle (n $=43 ; 37.39 \%$ ), with epidural hematoma being the most common type of injury ( $\mathrm{n}=57 ; 49.57 \%)$. Most patients presented with mild traumatic brain injury (n $=87 ; 75.65 \%$ ), and of the 115 operative patients, 87 (75.65\%) patients had a GCS score of 14-15. Most of the patients were hospitalized for 3-5 days $(n=74$; $64.35 \%$ ), and made full recovery and were discharged $(\mathrm{n}=113 ; 98.26 \%)$, with only two $(1.74 \%)$ patients in the operative group reported dead (Table 1). 
Of the 181 non-operative patients, there were $120(66.3 \%)$ male patients, where children $(\mathrm{n}=68 ; 37.57 \%)$ and adolescents $(n=66 ; 36.46 \%)$ being the age group most often found in non-operative patients. In this group, falling while playing $(\mathrm{n}=59 ; 32.6 \%)$ were the most common cause of injury. Of the several types of head injuries encountered, brain concussion was found in 97 (53.59\%) patients. The majority of non-operative patients had GCS score of $14-15(\mathrm{n}=147 ; 81.22 \%)$, with only $1(0.55 \%)$ patients had GCS score of $\leq 8$. Most non-operative patients were treated for $1-3$ days $(n=131 ; 72.37 \%)$ and all patients fully recovered and were discharged (Table 2).

Table 1. Proportion of Traumatic Brain Injury Patients Based on Sex, Age, and Cause of Injury

\begin{tabular}{|c|c|c|c|c|c|c|}
\hline & \multicolumn{3}{|c|}{ Operative Patients } & \multicolumn{3}{|c|}{ Non-Operative Patients } \\
\hline & $n=115$ & $(\%)$ & Mean & $\mathrm{n}=181$ & $(\%)$ & Mean \\
\hline \multicolumn{7}{|l|}{ Gender } \\
\hline Male & 68 & 59,13 & & 120 & 66,3 & \\
\hline Female & 47 & 40,87 & & 61 & 33,7 & \\
\hline \multicolumn{7}{|l|}{ Age Group } \\
\hline$<12$ months & 11 & 9,57 & 3,2 months & 3 & 1,66 & 1,4 months \\
\hline $1-4$ years & 17 & 14,78 & 3,2 years & 44 & 24,31 & 3,1 years \\
\hline $5-10$ years od & 40 & 34,78 & 7,4 years & 68 & 37,57 & 7,5 years \\
\hline $11-18$ years & 47 & 40,87 & 14,1 years & 66 & 36,46 & 14,6 years \\
\hline \multicolumn{7}{|l|}{ Cause of Injury (ICD-10) } \\
\hline Negligence (W04) & 10 & 8,7 & & 7 & 3,87 & \\
\hline Falling while playing (W09) & 28 & 24,35 & & 59 & 32,6 & \\
\hline Falling from bicycle (V18) & 27 & 23,48 & & 43 & 23,76 & \\
\hline Falling from motor vehicle (V28) & 43 & 37,39 & & 49 & 27,07 & \\
\hline Motor vehicle collision (V29) & 7 & 6,09 & & 20 & 11,05 & \\
\hline Slips (W01) & 0 & 0 & & 3 & 1,66 & \\
\hline
\end{tabular}

Table 2.Proportion of Traumatic Brain Injury Patients Based on Type of Injury, Glasgow Coma Scale, Length of Stay, and Discharge Condition

\begin{tabular}{|c|c|c|c|c|c|c|}
\hline & \multicolumn{3}{|c|}{ Operative Patients } & \multicolumn{3}{|c|}{ Non-Operative Patients } \\
\hline & $n=115$ & $(\%)$ & Mean & $n=181$ & $\%$ & Mean \\
\hline \multicolumn{7}{|l|}{ Type of Injury (ICD-10) } \\
\hline Epidural Hematoma (S06.4) & 57 & 49,57 & & 9 & 4,97 & \\
\hline Subdural Hematoma (S06.5) & 16 & 13,91 & & 5 & 2,76 & \\
\hline Impression Fracture (S02.0) & 19 & 16,52 & & 5 & 2,76 & \\
\hline Subperiosteal Hematoma (R58) & 13 & 11,3 & & 0 & 0 & \\
\hline Subarachnoid Hemorrhage (S06.6) & 0 & 0 & & 11 & 6,08 & \\
\hline Intracerebral Hemorrhage (S06.3) & 9 & 7,83 & & 2 & 1,1 & \\
\hline Cerebral Concussion (S06.0) & 0 & 0 & & 97 & 53,59 & \\
\hline Cerebral Edema (S06.1) & 0 & 0 & & 13 & 7,18 & \\
\hline Cerebral Contusion (S06.2) & 0 & 0 & & 39 & 21,56 & \\
\hline Foreign Body (S01) & 1 & 0,87 & & 0 & 0 & \\
\hline \multicolumn{7}{|l|}{ Glasgow Coma Scale } \\
\hline Mild (14-15) & 87 & 75,65 & & 147 & 81,22 & \\
\hline Moderate (9-13) & 23 & 20 & & 33 & 18,23 & \\
\hline Severe $(\leq 8)$ & 5 & 4,35 & & 1 & 0,55 & \\
\hline \multicolumn{7}{|l|}{ Length of Stay } \\
\hline 1-3 days & 1 & 0,87 & 3 days & 131 & 72,37 & 2,9 days \\
\hline 3-5 days & 74 & 64,35 & 4,9 days & 12 & 6,63 & 4,6 days \\
\hline$>5$ days & 40 & 34,78 & 7,9 days & 38 & 21 & 7,5 days \\
\hline \multicolumn{7}{|l|}{ Discharge Condition } \\
\hline Recovered & 113 & 98,26 & & 181 & 100 & \\
\hline Death & 2 & 1,74 & & 0 & 0 & \\
\hline
\end{tabular}




\section{DISCUSSION}

Of 115 operative patients and 181 non-operative patients, most were male patients. From several previous studies conducted by Dewan, et $\mathrm{al}^{6}$ Alhabdan, et $\mathrm{al}^{8}$ and El-Menyar, et $\mathrm{al}^{9}$ up to $80 \%$ of pediatric traumatic brain injury patients were male. The high incidence of traumatic brain injury in men may be related to the high use of motor vehicles, lack of road safety awareness, and may be attributed to adventurous and aggressive behavior. ${ }^{3,10}$

The number of adolescent patients (11-18 years) in the operative group in this study could be related to the cause of injury. In addition, in this study, it was found that traumatic brain injury caused by falling from motor vehicle was the most common cause in operative patients. In adolescent age group, the use of motor vehicle that are not accompanied by road safety awareness can increase the incidence of traffic accidents. ${ }^{3}$ According to Riskesdas 2018 data, around $23.9 \%$ of people of all age group never use helmets while riding motorbikes ${ }^{11}$ This is supported by a study conducted by Alhabdan, et al in which most traumatic brain injury patients were aged 15-18 years. ${ }^{8}$

In our study, it was found that most of the nonoperative patients are children over 5 years old. Research conducted in Qatar and Nepal also found similar results, namely that the highest incidence of traumatic brain injury was found in children over 5 years old which may be due to the high use of motor vehicles in adolescent groups.9,12 In addition, in children aged 5-10 years old, where the age range is school age and the high rate of traumatic brain injury in this group may come from accidents when children are playing in school without supervision ${ }^{9,12}$ In this study, it was also found that in the non-operative patients, the cause of most injury was due to falling while playing $(\mathrm{n}=59 ; 32.6 \%)$. This emphasizes the importance of supervision when children play, especially in school and home environments.

This study found that, in operative group, the most cases were epidural hematoma $(\mathrm{n}=57 ; 49.57 \%)$ (Figure 1). The previous studies by Tallapragada, et $\mathrm{a}{ }^{13}$ and Udoh, et $\mathrm{a}^{14}$ found that most of the operative measures were performed in cases of epidural hematoma. Meanwhile, in non-operative patients, the majority were cases of brain concussion $(\mathrm{n}=$ 97; 53.59\%) (Figure 2). However, study by Maas, et al found that subarachnoid hemorrhage was the most common pathology encountered, followed by cerebral contusion. ${ }^{15}$ Another study from Dewan, et $\mathrm{al}^{16}$ showed different results in that fracture and cerebral contusion were the most common pathologies found on head CT scan. Another result by El-Menyar, et al found that cerebral contusion is the type of injury that often occur in pediatrics. ${ }^{9}$ These varying results may be due to differences in sociodemographic factors that can influence the incidence of head injury. In addition, the varying number of subjects may also affect the results of the research obtained, therefore further research is needed on this matter.

In the operative and non-operative patients, mostly presented with a GCS score of 14-15, with only 1 $(0.55 \%)$ patients in the non-operative group came with a GCS score of $\leq 8$. This is quite in line with the study by Putra and Dewan, et al, where patients admitted to hospital with traumatic brain injury were mostly with GCS score of 14-15 (67.70\%). ${ }^{5,6}$ Another study by $\mathrm{Li}$, et al ${ }^{17}$ reported that mild traumatic brain injury (GCS 14-15) is the most common condition encountered.

The length of stay in the hospital of $74(64.35 \%)$ patients who underwent surgery was 3-5 days, followed by 40 patients $(34.78 \%)$ who were hospitalized for more than 5 days. Whereas in nonoperative patients, as many as 131 patients $(72.37 \%)$ required a short hospital stay, namely 1-3 days. The length of stay of patients is very dependent on their condition when arriving in the hospital and during their treatment. Study by Bedry, et a ${ }^{18}$ showed that the average length of stay in patients with traumatic brain injury was 4-7 days while another study by Tallapragada, et $a{ }^{13}$ showed shorter length of stay of less than 2 days in $75 \%$ non-operative pediatric traumatic brain injury patients. The longer length of stay in patients who undergo surgery may be due to pre-operative management and post-operative care which takes longer time compared to patients who do not undergo surgical procedure.

In both groups, almost all patients recovered and discharged. Of the 115 patients in the operative group, two $(1.75 \%)$ patients died, while in the non-operative group, all patients recovered and discharged. This shows that despite of the initial condition, with the right management, there is a chance of recovery in traumatic brain injury patients. On the other side, one patient came with significantly worse condition (GCS $<8$, extensive bleeding) leading to death despite adequate management. However, some complications during hospitalization may occur and have the opportunity to worsen patient's condition 
such as sepsis and pneumonia as reported in the study by El-Menyar, et al. ${ }^{9}$ where in this study, postoperative complication in which infection occurred in the other patient during hospitalization leading to death of the patient. This could be prevented by closer monitoring of operative patients and proper emergency medical services.

In conclusion, head injury patients were predominantly male in the adolescent age group due to falling from motor vehicles. Based on the type of injury, epidural hematoma and brain concussion were the most common type of injury. The majority of patients recovered and discharged. This study has several limitations in which we do not evaluate the delayed outcome that might occur and the use of purposive sampling might not represent the whole population. This study provides an overview of pediatric patients with traumatic brain injury in which the results are related to the importance of road safety awareness and supervision from parents in order to reduce morbidity and mortality in pediatric patients.

\section{Acknowledgment}

The author(s) would like to express sincere gratitude to the Director of Wongsonegoro Regional Public Hospital Semarang for the support and encouragement of this study and research.

\section{REFERENCES}

1. Schneier AJ, Shields BJ, Hostetler SG, Xiang H, Smith GA. Incidence of pediatric traumatic brain injury and associated hospital resource utilization in the United States. Pediatrics. 2006; 118 (2) 483-92

2. Da Dalt L, Marchi AG, Laudizi L, Crichiutti G, Messi G, Pavanello L, et al. Predictors of intracranial injuries in children after blunt head trauma. European Journal of Pediatrics. 2006;165:142-8.

3. Moya Zamzami N, Fuadi I, Nawawi AM. Angka kejadian dan outcome cedera otak di RS. Hasan Sadikin Bandung Tahun 2008-2010. JNI. 2013;2(2):89-94.

4. Rosyidi RM, Priyanto B, Laraswati NKP, Islam AA, Hatta M, Bukhari A, et al. Characteristics and clinical outcome of traumatic brain injury in Lombok, Indonesia. Interdisciplinary Neurosurgery. 2019 Dec $1 ; 18: 100470$.

5. Putra MB. Karakteristik pasien cedera kepala di Rumah Sakit Umum Daerah (RSUD) Umbu
Rara Meha Waingapu periode 1 Januari 2017 - 31 Desember 2018. Intisari Sains Medis. 2019;10(2): $511-515$

6. Dewan MC, Mummareddy N, Wellons JC, Bonfield CM. Epidemiology of global pediatric traumatic brain injury: qualitative review. World Neurosurgery. 2016;91:498

7. Dewi MR, Mangunatmadja I, Ramli Y. Karakteristik klinis trauma kepala pada anak di RS Dr. Cipto Mangunkusumo Jakarta. Sari Pediatri. 2016;9(5):354-8

8. Alhabdan S, Zamakhshary M, Alnaimi M, Mandora $\mathrm{H}$, Alhamdan M, Al-Bedah K, et al. Epidemiology of traumatic head injury in children and adolescents in a major trauma center in Saudi Arabia: implications for injury prevention. Annals of Saudi Medicine. 2013;33(1)52-6

9. El-Menyar A, Consunji R, Al-Thani H, Mekkodathil A, Jabbour G, Alyafei KA. Pediatric traumatic brain injury: a 5-year descriptive study from the National Trauma Center in Qatar. World Journal of Emergency Surgery. 2017 Nov 7;12:48.

10. Rohana J, Ong LC, Hassan AAA. Epidemiology of head injury in Malaysian children: a hospital-based study. Med J Malaysia. 1998;53(3):6.

11. National Institute of Health Research and Development. Report of national basic health research 2018. Jakarta: The Institute; 2018.

12. Gupta PP, Malla GB, Bhandari R, Kalawar RPS, Mandal M. Patterns of injury and mortality in pediatric patients attending emergency department in a tertiary care center in Eastern Nepal. Journal of the Nepal Medical Association. 2017; 56(207):331-4

13. Tallapragada K, Peddada RS, Dexter M. Paediatric mild head injury: is routine admission to a tertiary trauma hospital necessary? ANZ Journal of Surgery. 2018; 88(3):202-6

14. Udoh DO, Adeyemo AA. Traumatic brain injuries in children: a hospital-based study in Nigeria. African Journal of Paediatric Surgery. 2013; 10(2):154-9

15. Maas AIR, Menon DK, Steyerberg EW, Citerio G, Lecky F, Manley GT, et al. Collaborative European neurotrauma effectiveness research in traumatic brain injury (CENTERTBI): A prospective longitudinal observational study. Neurosurgery. 2015; 76(1):67-80.

16. Dewan MC, Mummareddy N, Wellons JC, Bonfield CM. Epidemiology of global pediatric traumatic brain injury: qualitative review. World Neurosurgery. 2016;91:497-509.e1.

17. Li M, Zhao Z, Yu G, Zhang J. Epidemiology of traumatic brain injury over the world: a systematic review. General Medicine. 2016; 1(2):1007

18. Bedry T, Tadele H. Pattern and outcome of pediatric traumatic brain injury at Hawassa University Comprehensive Specialized Hospital, Southern Ethiopia: observational cross-sectional study. Emergency Medicine International. 2020; 2020: 1-9 